Gut, 1971, 12, 912-917

\title{
Ischaemic enterocolitis: an expression of the intravascular coagulation syndrome
}

\author{
R. WHITEHEAD \\ From the Department of Pathology, Radcliffe Infirmary, Oxford
}

SUMMARY In 20 cases of ischaemic enterocolitis unassociated with lesions of major vessels, fresh thrombi were found in the small vessels of the bowel wall and were widespread in other tissues. The capillaries of the renal glomeruli and vessels in the lung were the commonest sites. Pseudo-membranous enterocolitis is shown to be an early or more slowly evolving but identical entity to other forms of so-called ischaemic enterocolitis. This is a condition which includes ischaemic enterocolitis, postoperative enterocolitis, necrotizing enterocolitis, and probably some cases of clostridial and staphylococcal enterocolitis. It is due to an episode of intravascular coagulation occurring principally in the gut wall but also elsewhere.

When the intestine is deprived of an adequate blood supply a surprisingly wide variety of clinical and pathological states may result. Exclusion of those cases manifestly due to lesions of the vessels supplying the intestine still leaves a large group of cases similarly characterized by ischaemic necrosis in which neither arterial nor venous obstruction can be demonstrated. Terminology pertaining to these is confused and poorly defined and under the heading of ischaemic enterocolitis (Goulston and McGovern, 1965) and ischaemic colitis, group 1 gangrenous (Marston, Pheils, Thomas, and Morson, 1966), are included cases previously entitled haemorrhagic enterocolitis (Wilson and Qualheim, 1954), necrotizing colitis (Killingback and Williams, 1961), Clostridium welchii colitis (Tate, Thompson, and Willis, 1965), uraemic colitis, postoperative enterocolitis, staphylococcal enterocolitis, and pseudomembranous enterocolitis although Goulston and McGovern regard this as a separate entity.

Those cases which for the purpose of this paper are called 'ischaemic enterocolitis' have no special tendency to involve only the splenic flexure, sometimes involving the whole of the large bowel and part of the small bowel. Although commoner in old ageno age group is exempt. Clinically there is usually a sudden onset of diarrhoea, sometimes containing blood, in severely ill patients in a terminal state, in shock, or in the postoperative period, and recovery is uncommon. By contrast ischaemic colitis due to major vascular occlusion or narrowing is commonly segmental and involves the splenic flexure and Received for publication 29 July 1971. neighbouring colon. Concomitant small intestinal lesions and rectal lesions are rare except in special circumstances and the patients are nearly always in the older age groups and commonly have other manifestations of vascular insufficiency. Clinically there is bloody diarrhoea in an otherwise fairly healthy patient and recovery with or without stricture formation is not infrequent.

In the absence of vascular occlusion or narrowing the lesions in ischaemic enterocolitis have been attributed to splanchnic hypoperfusion secondary to hypotension or vasoconstriction. One of the more or less characteristic histological features is, however, thrombosis of mucosal and submucosal vessels, and, whilst these have been regarded as a secondary phenomenon, the possibility that local thrombosis is primary must be considered. After noting the presence of disseminated thrombosis in cases of ischaemic enterocolitis coming to necropsy and in view of recent evidence for intravascular coagulation as a cause for other haemorrhagic lesions of the gastrointestinal tract, including pseudo-membranous colitis (Margaretten and McKay, 1971), a group of cases of ischaemic enterocolitis was studied in detail for the presence of disseminated thrombosis.

\section{Material and Methods}

Twenty cases of ischaemic enterocolitis were selected from the necropsy records of the Radcliffe Infirmary between 1948 and 1968 from material previously filed under the heading of ischaemic colitis or uraemic enterocolitis, pseudo-mem- 
branous enterocolitis, postoperative enterocolitis, and staphylococcal enterocolitis. Only those in which the absence of major vascular pathology was specifically noted were included, others being rejected because of inadequate macroscopic descriptions or incompatible histological appearances. In each case several sections of affected intestine and sections from at least six other tissues or organs, including lungs and kidney, were stained by the haematoxylin and eosin, Lendrum's MSB, and picro-Mallory methods. They were examined for the presence of recent thrombi. As a control similarly prepared sections of lung and kidney from 10 unselected cases which had recently come to necropsy were also examined.

\section{Results}

No thrombi were found in the control cases. The site of involvement of the bowel and the location of thrombi in other organs and tissues in the cases of ischaemic enterocolitis is indicated in Table $I$.

\section{MACROSCOPIC APPEARANCES OF THE INTESTINE}

From the outside the bowel affected may appear unremarkable or dilated and slightly injected but may be somewhat reddened or darker. The appearance of obvious intestinal gangrene, such as is associated with mesenteric vascular occlusion or strangulation of the bowel, was not a feature in this series, but in one case there was a full-thickness ischaemic necrosis of the caecum with perforation and peritonitis. Internally the affected mucosa appears reddened and haemorrhagic and the intestinal contents may be red and bloody or darker in older lesions. Redness appears to be due to hyperaemia and ulceration which may be superficial pinpoint, or deeper and transverse, longitudinal or serpiginous. The ulcers have necrotic ragged margins and there may be extensive areas of complete ulcerative loss of mucosa. Adherent or sloughed membranous material of yellow necrotic appearance is sometimes seen and a distinctive appearance which may be generalized throughout the bowel is that of multiple discrete dome-shaped or less regular membranous plaques scattered over a diffusely hyperaemic background. It is this type of case which is often referred to as pseudo-membranous enterocolitis.

\section{HISTOLOGICAL APPEARANCES OF THE} INTESTINE

The earliest lesion appears to be thrombosis involving the capillary plexuses high up in the intestinal mucosa (Fig. 1). These are present before there is mucosal necrosis and serial sections have proved that they are not just lesions at the edge of membranous plaques or larger lesions. Later there is necrosis of the superficial layers of the mucosa with oedema and haemorrhages and an acute inflammatory infiltrate in the lamina propria with extension of the thrombosis to involve submucosal vessels (Fig. 2). The appearances in so called pseudo-membranous cases (Fig. 3) suggests a slower evolution. Superficial capillary thrombi are present and in patches the superficial mucosa becomes necrotic. The oedema and inflammatory infiltrate seem to obstruct the mouths of glands causing mucus retention and cystic dilatation in their deeper parts. Plaques of

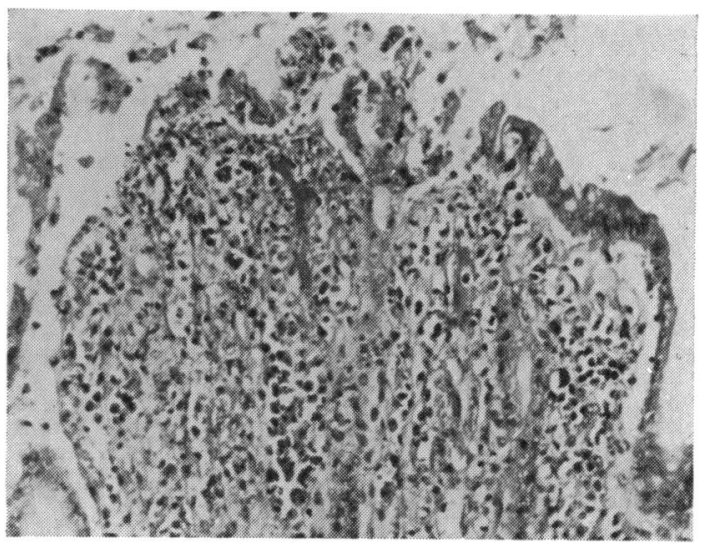

Fig. 1 Thrombosed apical capillary loop. Mucosa otherwise shows only early postmortem change and a non-specific inflammatory infiltrate $(M S B \times 80)$.

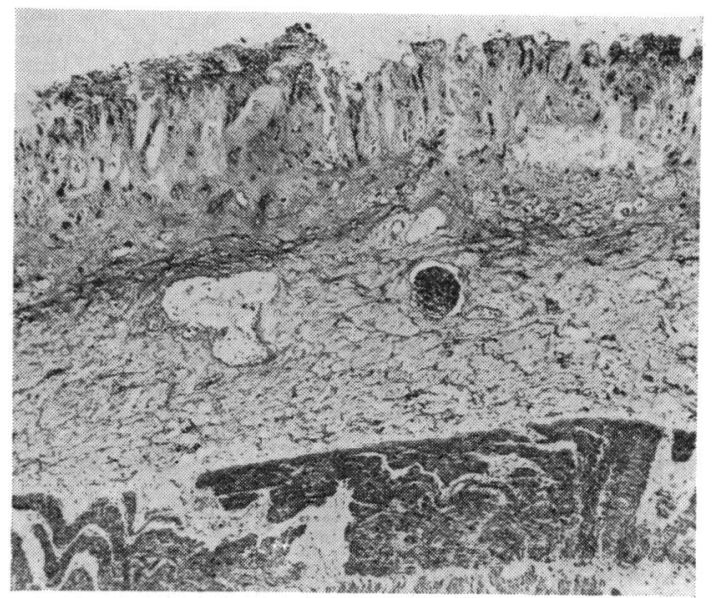

Fig. 2 Extensive mucosal capillary thrombosis with extension to submucosa. Upper layers of mucosa show ischaemic necrosis $(M S B \times 30)$. 


\begin{tabular}{|c|c|c|c|c|c|c|}
\hline Case No. & Age & Sex & Bowel Symptoms & Bowel Involvement & $\begin{array}{l}\text { Site of Thrombi in } \\
\text { Other Organs }\end{array}$ & $\begin{array}{l}\text { Comments and Coexistent } \\
\text { Disease }\end{array}$ \\
\hline 1 & 69 & $\mathbf{F}$ & $\begin{array}{l}\text { Bloody diarhoea for } \\
6 \text { days }\end{array}$ & Large bowel & Lung, kidney, heart & $\begin{array}{l}\text { Carcinoma of ovary, bilateral } \\
\text { hydronephrosis, uraemia }\end{array}$ \\
\hline 2 & 50 & $\mathbf{F}$ & $\begin{array}{l}\text { Bloody diarrhoea for } \\
6 \text { days }\end{array}$ & $\begin{array}{l}\text { Terminal ileum and } \\
\text { large bowel }\end{array}$ & Kidney, endocardium & Chronic pyelonephritis, uraemia \\
\hline 3 & 73 & $\mathbf{F}$ & Diarrhoea for 7 days & $\begin{array}{l}\text { Terminal ileum and } \\
\text { large bowel; rectum } \\
\text { spared }\end{array}$ & Lung & $\begin{array}{l}\text { Congestive heart failure, chronic } \\
\text { respiratory disease }\end{array}$ \\
\hline 4 & 73 & $\mathbf{M}$ & $\begin{array}{l}\text { Mild diarrhoea for } 8 \\
\text { days }\end{array}$ & $\begin{array}{l}\text { Large bowel (partly } \\
\text { pseudo-membranous) }\end{array}$ & $\begin{array}{l}\text { Kidney, heart, and } \\
\text { endocardium }\end{array}$ & $\begin{array}{l}\text { Myocardial infarction, severe } \\
\text { heart failure, terminal uraemia }\end{array}$ \\
\hline 5 & 80 & $\mathbf{M}$ & $\begin{array}{l}\text { Diarrhoea for } 11 \\
\text { days }\end{array}$ & $\begin{array}{l}\text { Descending and } \\
\text { sigmoid colon }\end{array}$ & Kidney, adrenal & $\begin{array}{l}\text { Prostatectomy: Staphylococcus } \\
\text { aureus cultured at necropsy }\end{array}$ \\
\hline 6 & 47 & $\mathbf{M}$ & $\begin{array}{l}\text { Diarrhoea (profuse) } \\
12 \text { hours }\end{array}$ & $\begin{array}{l}\text { Ileum, caecum, } \\
\text { ascending and trans- } \\
\text { verse colon; descen- } \\
\text { ding, pelvic colon, } \\
\text { and rectum spared }\end{array}$ & $\begin{array}{l}\text { Lung, kidney, adrenal, } \\
\text { pancreas, thyroid, } \\
\text { lymph nodes }\end{array}$ & $\begin{array}{l}\text { Partial gastrectomy for duodenal } \\
\text { ulcer, numerous Gram-positive } \\
\text { cocci in bowel mucosa }\end{array}$ \\
\hline 7 & 69 & $\mathbf{M}$ & $\begin{array}{l}\text { Abdominal pain and } \\
\text { vomiting } 2 \text { days }\end{array}$ & $\begin{array}{l}\text { Ileum and large } \\
\text { bowel; sparing of } \\
\text { rectum below } \\
\text { carcinoma }\end{array}$ & $\begin{array}{l}\text { Adrenal, pancreas, } \\
\text { thyroid }\end{array}$ & $\begin{array}{l}\text { Transverse colostomy for } \\
\text { obstruction-carcinoma of recto- } \\
\text { sigmoid }\end{array}$ \\
\hline 8 & 52 & $\mathbf{M}$ & None & $\begin{array}{l}\text { Large bowel; pelvic } \\
\text { colon and rectum } \\
\text { spared }\end{array}$ & $\begin{array}{l}\text { Kidney, brain, } \\
\text { pancreas }\end{array}$ & $\begin{array}{l}\text { Chronic focal glomerulo- } \\
\text { nephritis; hypertension, uraemia } \\
\text { (renal capillary thrombi in } \\
\text { otherwise normal glomeruli) }\end{array}$ \\
\hline 9 & 64 & $\mathbf{F}$ & Diarrhoea for 2 days & $\begin{array}{l}\text { lleum and large } \\
\text { bowel }\end{array}$ & Lung, kidney & Purulent pericarditis \\
\hline 10 & 65 & $\mathbf{F}$ & Diarrhoea for 1 day & Large bowel & Lungs, adrenal & $\begin{array}{l}\text { Gastroenterostomy and vagotemy } \\
\text { for duodenal ulcer }\end{array}$ \\
\hline 11 & 43 & $\mathbf{M}$ & Bloody diarrhoea & $\begin{array}{l}\text { Jejunum, ileum, and } \\
\text { large bowel; rectum } \\
\text { spared (caecal } \\
\text { perforation) }\end{array}$ & $\begin{array}{l}\text { Kidney, thrombi in } \\
\text { cavernous haeman- } \\
\text { gioma of liver }\end{array}$ & $\begin{array}{l}\text { Empyema following injury to } \\
\text { chest; staphylococci grown at } \\
\text { necropsy from empyema and gut; } \\
\text { early peritonitis }\end{array}$ \\
\hline 12 & 92 & $\mathbf{F}$ & Diarrhoea for 5 days & Pelvic colon & Lung & $\begin{array}{l}\text { Arthroplasty for fractured neck of } \\
\text { femur }\end{array}$ \\
\hline 13 & 67 & $\mathbf{M}$ & $\begin{array}{l}\text { Bloody diarrhoea for } \\
12 \text { days }\end{array}$ & Ileum and caecum & Lung, kidney & $\begin{array}{l}\text { Acute on chronic pyelonephritis, } \\
\text { chronic paraphimosis and } \\
\text { balanitis }\end{array}$ \\
\hline 14 & 41 & $\mathbf{F}$ & $\begin{array}{l}\text { Diarrhoea for } 18 \\
\text { days }\end{array}$ & $\begin{array}{l}\text { Terminal ileum and } \\
\text { large bowel (partly } \\
\text { pseudo-membranous) }\end{array}$ & Lung, kidney & $\begin{array}{l}\text { Infective diarrhoea with rest } \\
\text { of family; sudden collapse } \\
\text { diarrhoea became worse } \\
\text { Aspergillus pneumonia at necropsy }\end{array}$ \\
\hline 15 & 58 & $\mathbf{M}$ & $\begin{array}{l}\text { Abdominal } \\
\text { distension }\end{array}$ & $\begin{array}{l}\text { Terminal ileum and } \\
\text { large bowel (largely } \\
\text { pseudo-membranous) }\end{array}$ & Lung, kidney & $\begin{array}{l}\text { Suppurative bronchopneumonia } \\
\text { following influenza; } \\
\text { Staphylococcus aureus cultured } \\
\text { at necropsy from lungs and } \\
\text { bowel }\end{array}$ \\
\hline 16 & 59 & $\mathbf{M}$ & Mild diarrhoea & $\begin{array}{l}\text { Ascending colon } \\
\text { (partly pseudo- } \\
\text { membranous) }\end{array}$ & $\begin{array}{l}\text { Lungs, endocardium, } \\
\text { and aortic valve }\end{array}$ & $\begin{array}{l}\text { Vascular nephrosclerosis } \\
\text { uraemia }\end{array}$ \\
\hline 17 & 10 & $\mathbf{M}$ & None & $\begin{array}{l}\text { Terminal ileum and } \\
\text { large bowel }\end{array}$ & Lung, kidney & $\begin{array}{l}\text { Aplastic anaemia; } \\
\text { thrombocytopenia and systemic } \\
\text { moniliasis. }\end{array}$ \\
\hline 18 & 74 & $\mathbf{M}$ & $\begin{array}{l}\text { Bloody diarrhoea for } \\
6 \text { hours }\end{array}$ & $\begin{array}{l}\text { Ileum and large } \\
\text { bowel }\end{array}$ & Lung, adrenal & $\begin{array}{l}\text { Proliferative } \\
\text { glomerulonephritis }\end{array}$ \\
\hline 19 & 83 & $\mathbf{F}$ & Diarrhoea for 10 days & $\begin{array}{l}\text { S Large bowel } \\
\text { (completely pseudo- } \\
\text { membranous) }\end{array}$ & Lung, kidney, heart & $\begin{array}{l}\text { Skin graft for pressure sores } \\
\text { following fractured femur; } \\
\text { thrombosis of subclavian } \\
\text { artery }\end{array}$ \\
\hline 20 & 38 & $\mathbf{F}$ & $\begin{array}{l}\text { Bloody diarrhoea for } \\
2 \text { days }\end{array}$ & $\begin{array}{l}\text { Terminal ileum and } \\
\text { large bowel }\end{array}$ & Lung, kidney & Mitral valvotomy \\
\hline
\end{tabular}

Table Site of involvement of bowel and of thrombi in other organs and tissues.

membranes on the surface consist of fibrin, inflammatory cells, mucus, and necrotic epithelium. Such lesions are seen throughout the colon in pseudomembranous cases and intervening mucosa is hyperaemic but intact and yet will exhibit occasional capillary thrombi. Isolated lesions essentially similar occur in later cases in which there is more advanced necrosis. Extensive submucosal venous thrombi occur and other vessels exhibit typical ballooning and red cell sludging. The inflammatory infiltrate may be pronounced and a 'phlegmonous' picture is not uncommon. Ulceration often extends into the submucosa and may involve the inner muscle layers and very rarely full-thickness necrosis of the bowel 


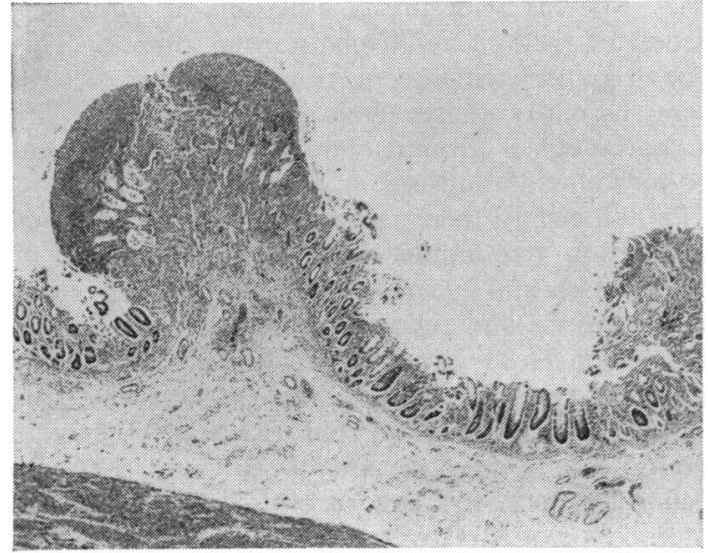

Fig. 3 Mixed fibrinoid, mucus and inflammatory cell superficial plaques with typical ballooning of deeper parts of glands in so-called pseudo-membranous enterocolitis $(M S B \times 18)$.

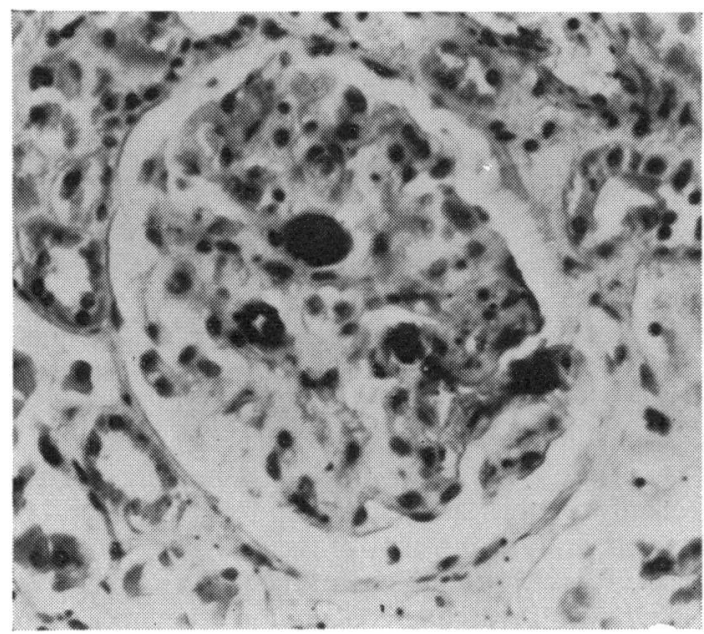

Fig. 4 Capillary thrombi in glomerulus $(M S B \times 270)$.

wall is seen. Thrombosis of small veins outside the bowel wall in the mesentery may also be present and was seen in two cases.

Sometimes colonies of organisms can be seen within the superficial necrotic tissues and in three of these Staphylococcus aureus had been cultured from the postmortem bowel. By and large the most severe lesions were seen in those cases with the longest history or those with an abrupt onset of severe shock, diarrhoea, and rapid death, eg, the fulminant cases. Those with a longer history and

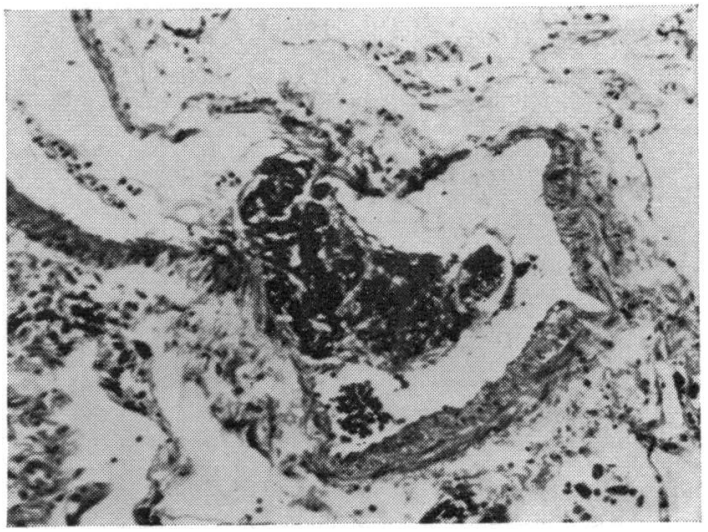

Fig. 5 Thrombus in pulmonary vein and neighbouring capillaries $(M S B \times 108)$.

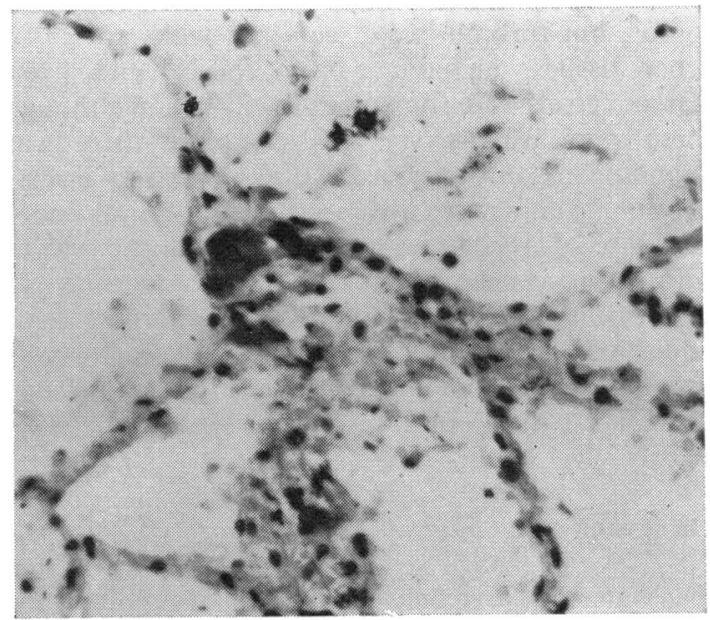

Fig. 6 Detail of capillary thrombi in lung (MSB $\times 270)$.

mild bowel symptoms were more likely to show superficial bowel mucosa involvement and included those with 'pseudo-membranous' lesions.

\section{HISTOLOGICAL FINDINGS IN OTHER} TISSUES

In all cases examined fibrin thrombi giving a positive staining reaction with the MSB and picroMallory methods were found in the vessels of other organs. In some cases thrombi were frequent but in others they were found only after a thorough search. 


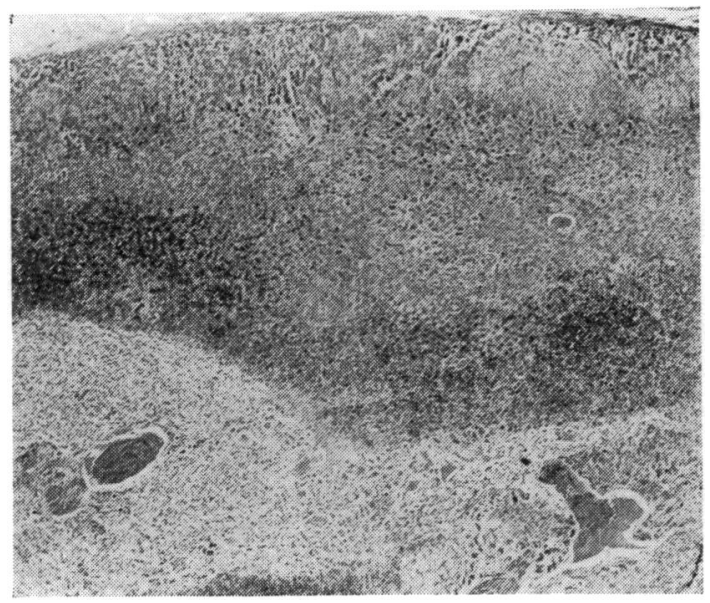

Fig. 7 Thrombosed adrenal vessels and haemorrhagic necrosis (darker zones) ( $H$ and $E \times 20)$.

Capillary thrombosis in the kidney glomeruli (Fig. 4) and thrombi in capillaries, small veins, and arteries in the lungs (Figs. 5 and 6 ) were the commonest findings by far, but thrombi were seen in a wide variety of other tissues, including, brain, heart, and liver. Larger vessels were sometimes involved and although these were usually veins in one case there was spontaneous thrombosis of the subclavian artery. Fibrin thrombi were also seen on the mural endocardium of the heart and on the aortic valves (presenting at necropsy as thrombotic endocarditis). It is of interest that in four cases the adrenal veins and sinusoids showed thrombosis and in one this was extensive and accompanied by early haemorrhagic necrosis of the Waterhouse-Friderichsen type (Fig. 7).

\section{Discussion}

The watershed area between the area of supply by the superior and inferior mesenteric vessels is the region of the splenic flexure (Griffiths, 1956). This is the area most commonly made ischaemic when there is occlusion or narrowing of the mesenteric vessels. The comparative rarity of ischaemic lesions in spite of the relatively common finding of such vascular pathology at necropsy speaks highly for the rich anastomotic network of vessels supplying the intestine. The correlation between ischaemia of the gut of this zonal type and arterial disease is not always good (Dick, Graff, McGregg, Peters, and Sarner, 1967) and the position is clearly analogous to coronary artery disease and myocardial lesions. Single vessel thrombosis in an otherwise healthy coronary circulation produces infarction in some cases whereas widespread atheroma in others is associated with a relatively normal muscle. This type of gut ischaemia seems to be a problem distinct from the entity of ischaemic enterocolitis not only on pathological grounds but also on the clinical grounds already outlined.

Pathologically there is apparently no pattern of distribution determined by the blood supply of major vessels and in early pseudo-membranous cases typical lesions and relatively normal mucosa occur side by side. Ischaemia occurring initially at capillary level would explain this pattern of involvement. This finding is typical of all the cases of ischaemic enterocolitis examined and it is clear that the pseudo-membranous enterocolitis and ischaemic enterocolitis of McGovern and Goulston (1965) and Goulston and McGovern (1965) are the same entity but of a different stage of evolution and severity.

The presence of occasional lesions in the mesenteric veins of some of these cases also suggests a relationship with so-called primary mesenteric vein thrombosis. There is little doubt that once ischaemic necrosis is established bacterial invasion is quick to follow and secondary invasion by organisms already in the bowel may be responsible for at least some cases of Clostridial and staphylococcal enterocolitis.

The pattern of distribution of thrombi in the gut wall, kidney, and lung capillaries, and in other organs closely parallels that seen in intravascular coagulation experimentally induced by thrombin infusions (McKay, Linder, and Cruse, 1971). The site of thrombosis can be modified by using other agents in conjunction with thrombin, eg, epsilonaminocaproic acid, histamine, serotonin, steroids, adrenalin and noradrenalin, and depends on the state of activation or inhibition of the fibrinolytic mechanism, the adequacy of renal glomerular filtration, and the integrity of the reticuloendothelial system. It is clear that many of the factors which can precipitate intravascular coagulation often operate in patients with ischaemic enterocolitis and include endothelial damage due to prolonged hypotension, tissue damage after surgical operations, malignancy, infection, shock, and Gram-negative endotoxaemia.

It is now widely recognized that the generalized Schwartzman reaction is but a manifestation of intravascular coagulation initiated by injection of bacterial endotoxin (Evenson and Hjort, 1970). A Schwartzman-like phenomenon localized to vessels in certain organs may also be responsible for quite distinct clinical entities, eg, the WaterhouseFriderichsen syndrome (Lo, Hitzig, and Frick, 1971), and it is of interest that in one out of four cases showing adrenal thrombi in this series there was early haemorrhagic parenchymal necrosis. The 
factor or combination of factors which cause more or less localization of the coagulation to one or other organs in human disease are yet to be determined.

Perhaps the best evidence for intravascular coagulation during life is the presence of fresh thrombi in postmortem tissues. Coagulation studies using postmortem blood are valueless but corroborative evidence of intravascular coagulation would be possible if these cases were investigated during life. Then depletion of coagulation factors and platelets and the presence of fibrin degradation products would be significant, especially if arteriovenous differences in the levels of these factors were shown to occur across the involved bowel. These are the lines along which further investigation might lead to those factors which indicate and localize the process of coagulation to the bowel. It is clear that the closest cooperation between physician, surgeon, and pathologist is needed in this endeavour.

References

Dick, A. P., Graff, R., McGregg, D., Peters, N., and Sarner, M.
(1967). An arteriographic study of mesenteric arterial disease: large vessel changes. Gut, 8, 206-220.

Evanson, S. A., and Hjort, (1970). Pathogenesis of disseminated intravascular coagulation. Plenary scientific contributions. XIIIth International Congress of Haematology, pp. 109-120, Lehmanns, Munich.

Goulston, S. J. M., and McGovern, V. J. (1965). Pseudo-membranous colitis. Gut, 6, 207-212.

Griffiths, J. D. (1956). Surgical anatomy of the blood supply of the distal colon. Ann. roy. coll. Surg., 19, 241-256.

Killingback, M. J., and Williams, K. L. (1961). Necrotizing colitis. Brit. J. Surg., 49, 175-185.

Lo, S. S., Hitzig, W. H., and Frick, P. G. (1971). Clinical experience with anticoagulant therapy in the management of disseminated intravascular coagulation in children. Acta haemat. (Basel), 45, 1-16.

Margaretten, W., and McKay, D. G. (1971). Thrombotic ulceration of the gastrointestinal tract. Arch. intern. Med., 127, 250-253.

Marston, A., Pheils, M. T., Thomas, M. L., and Morson, B. C. (1966). Ischaemic colitis. Gut, 7, 1-15.

McGovern, V. J., and Goulston, S. J. M. (1965). Ischaemic enterocolitis. Gut, 6, 213-220.

McKay, D. G., Linder, M. M., and Cruse, V. K. (1971). Mechanisms of thrombosis of the microcirculation. Amer. J. Path., 63, 231-241.

Tate, G. T., Thompson, H., and Willis, A. T. (1965). Clostridium welchii colitis. Brit. J. Surg., 52, 194-197.

Wilson, R., and Qualheim, R. E. (1954). A form of acute hemorrhagic enterocolitis affecting chronically ill individuals. Gastroenterology, 27, 431-444. 